Article

\title{
Secularized and Multi-Religious Classroom Practice-Discourses and Interactions
}

\author{
Karin Kittelmann Flensner \\ Department of Social and Behavioural Studies, University West, S-461 86 Trollhättan, Sweden; \\ karin.kittelmann-flensner@hv.se
}

Received: 28 June 2018; Accepted: 19 July 2018; Published: 7 August 2018

\begin{abstract}
Secularization and diversity are two social features that characterize the contemporary world. The rhetoric of the public debate in a number of countries has become increasingly polarized and characterized by a "we" and "them" thinking that relates a national "we" to a specific religion. This occurs in part as a reaction to the changes in national monocultural paradigms as most communities today are characterized by pluralism regarding lifestyles, religion, language and geographical background. Thus, secularization processes are ongoing while many countries, not least Sweden, are becoming increasingly pluralistic and multi-religious. The school and classrooms are a mirror of the communities they are a part of. The aim of the article is to explore how secularization and increasing pluralism finds expression and interact in the classroom practice of Religious Education. The analysis is based on ethnographic data from classroom observations of Religious Education in four different Swedish upper secondary schools. The results indicate that secularism and non-religious positions are considered a neutral and objective position and that secularism is used as a way to maneuver diversity in the classroom which affects the possibilities of dialogue and understanding.
\end{abstract}

Keywords: religious education; secularization; pluralism; non-confessional; classroom observation; ethnography

\section{Introduction}

Today, public debates about religion, nation, belonging and multiculturalism are characterized by highly polarized tones. In recent years, right-wing and nationalist parties have, in many countries, grown in influence and the rhetoric in the public debate is in many ways characterized by a "we" and "them" thinking that relates a national "we" to a specific religion. This situation occurs given mono-cultural paradigm change and pluralism in opinions, lifestyles, worldviews and linguistic, geographic and cultural backgrounds that persists in most countries. Factors that used to function as unifying on a national level and advocating shared narratives-such as religion, view of national history, educational practices and cultural institutions-have today been replaced by a variety of belongings and narratives. Commercial actors and social media have substituted national radio and television that use to be institutions spreading shared accounts. Narratives now dominating many western countries have an individualistic approach and often relate to individuals' physical health and wellbeing. This situation applies to many countries, also Sweden. Sweden can be described as one of the most secularized countries in the world [1-3]. The public conversation in Sweden is often characterized by a strong religion-critical discourse and there is simultaneously an increase in ethnic, religious and cultural diversity there. As a result, Sweden is a country that can be described as both secular and multi-religious [4].

Schools are part of society and what happens in society also affects classrooms. Therefore, both secularization and increased diversity characterize Swedish classroom practices. Nilsson [5] used the term "un-generalizable classroom" to draw attention to the multitude of experiences and 
backgrounds that today are taken as facts in Swedish schools. Teaching guidelines also state that "Teachers should: take as the starting point for each individual student's needs, circumstances, experiences and thinking" [6]. This statement means that teachers need to relate to students' perceptions and experiences in the classroom both to do justice to person's uniqueness but also to adjust the teaching to learning capabilities/inabilities of the learner. In Sweden, Religious Education is a compulsory subject both in elementary school and in upper secondary school. On average, the pupils have 45 min of Religious Education a week in elementary school and 60 min during one year at upper secondary school. The subject is non-confessional and non-denominational and all students are taught together in the same classroom regardless of their religious affiliation or lack thereof. Religious Education (henceforward RE) addresses world religions, major non-religious worldviews and ethics. The overall aim of the subject is shown by this quotation:

Teaching in the subject of religion should aim at helping students broaden, deepen and develop knowledge of religions, outlooks on life and ethical standpoints and where applicable different interpretations of these. [ ... ] Teaching should take as its starting point a view of society characterized by openness regarding lifestyle, outlooks on life, differences between people and also give students the opportunity to develop a preparedness for understanding and living in a society characterized by diversity [7].

A challenge in this context is that there can be students with widely different experiences of religion and religious practices in the same classroom. Some identify with various religious traditions and others completely lack the kind of experiences and language for what it possibly could mean to be part of a religious tradition. Some classrooms are characterized by a wide variety of religious as well as non-religious worldviews. However, because Swedish society is highly segregated there are also classrooms characterized by a lack of diversity. Regardless of the experiences, opinions and beliefs of the students in a specific classroom, the teaching needs to prepare them to live in a society characterized by diversity. In classroom observations, it appears that a secularist, highly critical discourse dominates articulations about religion and religions in RE [8]. Studies have also shown that students with religious positions often find that RE contributes to the "othering" of religious believers $[9,10]$. At the same time, there are other Swedish classrooms in which "everyone" is a believer and see themselves as belonging to various religious traditions. In those contexts, a significant proportion of the students have a migration background and in the classroom practice, the conversation simultaneously relates to a secular majority community [11].

This article aims to analyze how secularization and different aspects of pluralism are articulated and interrelated in the classroom practice of RE.

\subsection{Religious Education in Sweden}

A challenge when speaking about the subject of RE in international contexts is that it refers to a school subject with a wide variety of goals and objectives. Different countries have found different ways of dealing with socially religious diversity in schools [12]. The empirical examples in this article are taken from a Swedish context. Therefore, a brief description of the subject's background and design in Sweden are provided. The Swedish subject of RE has its roots in confessional Christian RE. Since the 16th century, Sweden had a Lutheran state church. In school, students were taught the "pure evangelical Lutheran doctrine". In the 1800s, major social transformations occurred due to industrialization, urbanization and increasing religious diversity. In 1858, it became permissible to leave the Swedish church and several new free churches arose. Society in this sense became more diverse. The emerging labor movement and the free-church movement were both, for various reasons, critical to the fact that teaching about religion offered at publicly funded schools was strongly linked to baptismal teaching and confirmation in the Church of Sweden. The labor movement and the free-churches threatened to start their own schools and in 1919 the Swedish parliament chose to prioritize school as a unifying factor and reduce RE's emphasis on preparation for catechism. The subject of RE was revised to a more general Christian orientation with a strong emphasis on 
ethics and personality development. In the 40's and 50's, an intense debate was held about beliefs and knowledge. In the 1960s, an "objectivity requirement" was introduced in RE.

Christian Religious Education must be conducted in a way that does not violate the individual's right to freedom of thought and belief. Therefore, instruction should be objective in the sense that it renders factual knowledge about the meaning and content of different creeds, without authoritatively seeking to influence pupils to include some opinion [13].

It stated that the subject would not try to influence students to adopt one or another life view. During this period, the subject changed its name to Knowledge about Religions [religionskunskap] [14]. The development of RE in Sweden can be described as initially teaching and learning in religion to teaching and learning from religion to now mainly be teaching and learning about religion [15]. Willaime [16] argued that the development of Swedish RE could be viewed as an example of secularization. He noted that the construction and development of the subject also might have contributed to the secularization of society.

\subsection{Secularization}

Sweden is often referred to as "the world's most secularized country", and this description is one that Swedes themselves often appreciate $[1,2,17]$. This narrative includes stories of the nation's development from being a Lutheran country with one king and one people united in one faith to a democratic society, free from religious oppression and characterized by strong individualism. This statement gives, of course, a simplified and partially incorrect picture but it works as a narrative about modern secularized Sweden that everybody has to relate to.

The concept of secularization attempts to describe a process in which religion is becoming less important for cultures, societies, institutions and individuals. One way of defining secularization is to view it as a differentiation process. Dobbelaire [18] divided secularization into three levels: social, organizational/institutional and individual. Secularization at the social level means that areas previously controlled by the church are instead controlled by a secular state. The organizational/institutional level concerns areas such as education, healthcare and social services and these became the state's responsibility. In other words, the emergence of the welfare state where the state stands as a guarantor for citizens' security is viewed as a contributing factor to secularization. This could be seen as an explanation why secularization is so apparent in Scandinavia in general and Sweden in particular-these countries have a strong secular state and a well-developed welfare system. At the individual level religion becomes less important for meaning-making and life-orientation. Cassanova [19] takes the same line and describes secularization as a process where secular institutions increasingly take over previously religiously dominated areas and norms, a reduction of religious beliefs and religiously motivated actions and a shift of religion from the public sphere to the private. Secularization decreases the influence of religious thinking, religious practices and religious institutions in society at large. Religion and politics are separated and scientific knowledge takes over as the valid knowledge [20]. Others, such as Taylor [21] emphasize the importance of pluralism for secularization. Pluralism in this context refers to differences in backgrounds, experiences and opinions in various contexts. The concept is sometimes used normatively and therefore associated with positive values attributed to religious diversity [22,23]. Thalén [24] maintained that plurality based on enlightenment ideas could enhance the dichotomization of religious-non-religious as identity markers where the inner variation is rendered invisible. These kinds of absolute differences are problematic in classrooms in the contemporary pluralistic world. In this article, pluralism is used descriptively to refer to different experiences, views and worldviews, religious as well as non-religious, coexisting within society and the classrooms.

Berger [25] coined the expression "the sacred canopy". This phrase refers to the meaning system that protects individuals regarding providing context and meaning; it is especially activated in life crises when the questions about the meaning and purpose of life are put to the forefront. How is this kind of opinion system preserved? Berger [25] and Taylor [21] emphasized that modern society 
is characterized by competing meaning systems. If different actors claim to be true, some must be wrong. Or is everybody wrong? One idea that might occur in this situation is that there might be no ultimate truth. This process is dialectical; pluralism undermines the reasonableness of the monopolistic religious movement's claim to possess the only truth because more than one way of thinking suddenly exists. Taylor stated: "The shift to secularity in this sense consists, among other things, of a move from a society where belief in God is unchallenged and indeed unproblematic, to one in which it is understood to be one option among others and frequently not the easiest to embrace" [21] (p. 3). These options then compete with the old institutions and further reduce their credibility. Secularization becomes a consequence of the plurality of possible worldviews. Because people in modern society have access to so much information and the ability to travel and meet people with different backgrounds, pluralism is an inevitable consequence. It becomes a key concept for understanding secularization and also what is perceived as religion. Another aspect of pluralism related to secularization is how new generations relate to traditions, practices and narratives used by previous generations to create meaning. A consequence of modernity is that traditions (religious and other) are not perceived as authoritative either in terms of patterns of action or beliefs or as a source of knowledge for their own existence. Hervieu-Léger [26] described traditions as a reference to a "chain of belief" and that a tradition consists of identification with these shared narratives, interpretations and practices that have both an individual a collective and a historical dimension. She believes that fragmentation, individualization and subjectivation mean that individuals and groups, to a much lesser extent, have access to a common language for this kind of phenomenon. Ultimately, the individual is deprived of access to the collective memories related to religion and tradition that previous generations were part of and also maintained. In this context, religion is defined as a "chain of memory", and secularization means that this chain is fragmented [26].

\subsection{Research on Secularization, Pluralism and Youth}

Research that focuses on how young people in Sweden relate to religiosity and secularization is consistent with the picture of Sweden as a secular country noted above. In quantitative studies, Western youth generally does not participate in religious practices to a large extent [27-29]. Although there are major variations within the group of young people both within and between different national contexts, it is clear that for a significant proportion of young people religion is neither particularly cool nor important [30,31]. What matters to many young people is instead family, friends and close relationships. However, the reality is always complex and many times contradictory, especially when it comes to religion. Knauth, Jozsa, Bertram-Troost and Ipgrave [32] found that while religion appeared to be less socially important, participation of young people in certain groups such as Pentecostal movements in England and other parts of the world was increasing. It also appears that religion is becoming more and more privatized; one can embrace perceptions usually attributed to a religious worldview without being part of traditionally organized communities. "Believing without belonging" [33] still seems to be characteristic of younger generations. However, many people say that they want to learn more about religion [34]. In Sweden, both quantitative and qualitative studies have put forth a view of religion and religiosity strongly characterized by individualism and privatization [35-39].

Parallel with the fact that religion as a phenomenon and cohesive factor changes and decreases in significance, pluralism in society increases regarding religious and other traditions, worldviews and lifestyles. In international research reviews, much of the RE research, both in confessional and non-confessional RE, focuses on various aspects of a pluralistic society $[8,40,41]$. There have also been a large number of studies highlighting different degrees of "othering of the religious" in school contexts $[9,14,42-47]$. Social processes such as globalization, increased migration and mobility, also means that the idea of nation and nationality is challenged and renegotiated. Sometimes notions of religion are a component of the national identity in terms of myths, metaphors and symbols. The relationship between nation, nationalism and religion is complex and can be seen in the light of the public debate on notions of nationality, homogeneity and monoculturalism [48]. Research draws 
attention to the complex relationships between minority and majority groups, how these relationships are negotiated by young people and how they shape their identity in relation to their ethnic and religious family background and a secular majority society [49-52]. The changing religious landscape creates the need for a new language to describe what is normally termed "religious", "non-religious", and "secular" $[17,53,54]$.

\subsection{Secularization and Pluralism in the Swedish Context}

As noted above, secularization is widespread in Sweden in several respects. In the sense of separation between public state-governed and religious institutions, Swedish law states that the state should be religiously neutral but also a guarantor of freedom of religion. An individual's right to freely encompass and practice religious or non-religious worldviews individually and together with others is part of the Swedish constitution. Furthermore, individuals possess the right not to be subjected to religious influence. Discrimination because of religious belonging is prohibited. Sweden no longer has a state church and the state should according to the law remain neutral in religious matters. Institutions such as health care and education are regulated by law and must be non-confessional and non-discriminatory. Faith schools in which there may be voluntary confessional elements outside the classroom are allowed but only $1 \%$ of children in Sweden attend a faith school and their teaching follows the same curriculum as other schools run by the municipality. This separation between a secular state and individuals' private life has strong support in society and religion is perceived as a private matter. On occasions when religion becomes visible in the public sphere (e.g., Muslim prayer calls, ending the school year in the church or when people for religious reasons do not wish to be greeted by hand), heated discussions arise about the boundaries of freedom of religion.

Even regarding the importance of religion to people's identities and perceptions of life, Sweden can be described as a country in which secularization is widespread. According to international surveys, there are relatively few people in Sweden who state that they embrace a religious worldview. In the aftermath of the Second World War, it became prohibited to register citizens' religious affiliation. However, different studies have attempted to chart how Swedes look at religion and religious identity. The proportion of atheists or non-believers is over 55\% in Sweden; Europeans, on average, are characterized by a religious identity in $77 \%$ of cases [55]. Other studies have shown that $45 \%$ of people in Sweden believe in God, $22 \%$ pray to God at least once every three months and $12 \%$ participate in a service or religious meeting at least once a quarter [56]. Many people in Sweden are safe in their non-religious identity and perceive this identity to be part of a modern, liberal and tolerant attitude. Nevertheless, at the same time, $59 \%$ of the population are registered members of the Church of Sweden and nearly 800,000 people (as of 2015) were registered members of other religious communities receiving state support. Of these, nearly 320,000 people were members in various free churches, 55,000 in different Lutheran churches, more than 110,000 in the Catholic church, 140,000 in different Eastern Orthodox Churches and 140,000 were members of different Muslim groups [57]. These numbers are based on registered membership, which means that there are far more individuals visiting mosques and churches who are not included in these statistics. The communities that are growing fall mainly in Eastern Orthodox Churches, the Catholic Church and various Muslim groups. If these statistics are the basis for measuring the degree of secularization in Sweden, the image of "the world's most secularized country" becomes more complex. Moreover, if one considers studies that investigated interest in spirituality in more comprehensive terms or people who were engaged in movements that can be referred to as New Age, the image is further complicated.

There is a notion that Sweden historically has been ethnically, linguistically and religiously a homogeneous society. This myth is easy to deconstruct because Sweden, like most countries, always has had a diverse population. Today, five national minorities are recognized: Samis, Tornedalers, Swedish Finns, Roma and Jews, all of which have a long history in Sweden [58]. However, population heterogeneity increased in recent decades as a consequence of globalization and increased migration [59]. Increased immigration has also led to increased religious diversity in 
Swedish society [57]. In population statistics, "foreign background" is defined as a person born in another country or having two parents born in another country. Using this definition, $24.1 \%$ of the Swedish population in 2017 has a foreign background [59] but people with foreign backgrounds are not evenly distributed throughout the country. In some municipalities, more than $50 \%$ of people foreign backgrounds; most municipalities have about $10-20 \%$ inhabitants with this background of such people [60]. In many municipalities, segregation in housing is high and socially and economically disadvantaged groups dominate in some areas where unemployment and long-term unemployment are higher and average income levels and education levels are lower, which further deepens the segregation. The schools' compensatory mandate to equalize these kinds of differences is accordingly more critical but evaluations show that the equivalence in quality between schools is declining and that this se has been widening in recent decades [61].

These are some ways to describe and highlight the increased diversity that characterizes Swedish society. These social processes mean that it is difficult to talk about what a "Swedish classroom" looks like because the variation is abundant. In some classrooms, it is the norm to have a religious identity while simultaneously relating to the secular majority outside the classroom. In other classrooms, the majority relate to what they perceive to be the majority perception in Sweden, namely a secular, at many times an atheist position. In these classrooms, religion is a private matter that is not shared with classmates. And in most classrooms, there is an ongoing conversation between individuals with a multitude of opinions and experiences. Nilsson [5] described these various conditions for teaching about religion and religions in terms of "the un-generalizable classroom" and "the unpredictable classroom", which is a relatable description of reality for many RE-teachers.

\section{Materials and Methods}

This work is based on classroom observations from two different research projects. The first research project consists of empirical material of participatory observations of RE classes at three Swedish upper secondary schools gathered in 2011-2012. A re-analysis [62] based on the purposes of this article have been conducted. To nuance and problematize the image that emerged in this empirical material, an analysis of data from an ongoing research project was also included. This research project focuses on how global religious conflicts are handled in teaching; the empirical material used in this article consists of participatory observations and interviews conducted in 2017 with teachers and students from a school with a high proportion of students with a migrant background based on the definition provided above. The age of the students in both research projects are 16-19 years old.

The participant classrooms observations in the research projects take an ethnographic approach [63]. In the first study, the teaching of 13 educated RE teachers of 24 different classes was followed for 125 lessons at both vocational programs and programs preparatory for higher education. The four schools were larger municipal schools with 1100-1700 students, one of which was near a larger city (School 1), one was in the countryside (School 2) and one was in a medium-sized Swedish city (School 3). School 4 was also situated near a large city but in an area that can be described as socially vulnerable. There are no statistics available pertaining to the pupils' ethnic or religious backgrounds at the individual schools. However, because this article focuses on various aspects of diversity, the schools will be described based on the available information about the background of the students. The school adjacent to the larger city (School 1) was a fairly popular school and had relatively high grades. Available statistics reveal that $14 \%$ of the students had foreign backgrounds (i.e., born in another country or having two parents born in another country) and that $66 \%$ of pupils had parents who were counted as being highly educated with post-secondary education. In the rural school (School 2), 11\% of pupils had foreign backgrounds and $47 \%$ had a secondary education. At the school in the medium-sized Swedish city (School 3), 28\% students had a foreign background and $42 \%$ had highly educated parents this academic year. In the current research project, the school (School 4) had $91 \%$ foreign-background students; only $21 \%$ of students had parents with a post-secondary education. 
Another measure that could be an indicator of diversity is how many students were entitled to native language education. An interesting difference between schools 1 and 3 was how the staff talked about their school as being "ethnically homogeneous" or "multicultural". On the first day of observations at School 1, one of the native language teachers came in and spoke with the students who studied Persian. I noted that five students in that class were eligible for native language education (i.e., $20 \%$ of the students). However, these students were high performing and had parents with high educational backgrounds; they were not perceived as immigrants when the teacher spoke about the student group. At School 3, the situation was the opposite. The school was described as a multicultural school by the staff but the proportion of students entitled to native language was only slightly higher, $20-30 \%$. However, the proportion of students with parents with a post-secondary education at this school was significantly lower, which I interpreted as the pupils' class background playing a role in how the teachers perceived the students' ethnicity. At School 4, the school was noted as being a multicultural school; it was assumed that "everyone" had an immigrant background. It is apparent from the statistics that students at School 4 also came from families with low educational backgrounds. However, this fact was not discussed.

\subsection{Analysis}

During the lessons, full-class discussions were recorded along with discussions in smaller groups. These recordings were transcribed verbatim. In the analyses, the classroom practice and what was said in the classroom were the focus rather than who said what or how the interaction between students or between students and teachers appeared. The classroom practice and articulations of students and teachers are considered to be a discursive practice [64]. The transcribed observations have been analyzed using a discourse analytical approach $[65,66]$ focusing on articulations concerning secularity and pluralism. Secularity and non-religious positions emerged as a hegemonic discourse when talking about religion. However, the reality is complex and contradictory and in the analyses of the empirical material discourses that challenged the hegemonic secular discourse also was found. For example, one of the noticeable discourses of religion were articulations of spirituality and to believe in "something". This way of speaking partly defied the secular discourse but partly enhanced it, as this individualistic approach to religion was compatible with a secularist view of religion as a private matter. Discourses of spirituality will however not be elaborated on in this article as the aim is to explore how secularization and different aspects of pluralism are articulated and interrelated in the classroom practice of RE. Nationalistic discourses including articulations of Sweden as a Christian country will be touched upon in relation to pluralism.

\subsection{Ethical Consideration}

Participant observation has been conducted in line with the ethical guidelines outlined by The Swedish Research Council [67]. The informants have received information about the study's design and purpose, that their participation is voluntarily and that they had the right to withdraw their participation at any time, that their integrity will be treated with confidentiality and how study will be used, that is utilization requirement. All research balances between respect for individuals' privacy, individual protection requirement and the benefits society may have of the research [67].

\section{Results}

The classroom observations were analyzed regarding how secularization and different aspects of pluralism were articulated and interrelated in the classroom practice of RE.

\subsection{Discourses of Secularism}

Discourses of secularism included articulations of what "we" in Sweden believe, religion as something belonging to history, the nonreligious as neutral and notions of individualism. 


\subsection{1. "We" in Sweden Are Secular}

During the classroom observations, it was clear that a non-religious and at many times a secularist attitude dominated the articulations about religion and religions. The following quote is a typical description of how religiosity related to secularity:

Teacher: We're so ENORMOUSLY secularized in Sweden. Religion has no place in most people's lives in any way. We may go to church once a year because there's some kid getting baptized or someone dies or something like that. And then we don't go there. That's pretty much the religiosity we have (School 2).

It was stated that "we" in Sweden are secular and that religion is of very little importance to Swedish people. Specific linguistic expressions such as "we" were used to create a common image of religiosity in Sweden. This pattern also contributes to constructing secularity as normal and constructing Sweden as a secular country in which most people have no relation to religious worldviews or practices. Through these kinds of articulations, the diversity of views is made invisible.

In all of the classrooms at all of the schools, there were students who identified with various religious traditions. In private conversations, the students noted that they were active in the Church of Sweden, the Uniting Church in Sweden, the Pentecostal Church, the Catholic Church, the Orthodox Church; they described themselves as following Jehovah Witness, Hindu, Buddhist, Shia and Sunni traditions. Students with a religious position were in most cases silent during whole-class discussions concerning religion, maybe partly due to the minority-majority position. At Schools 1 and 2, only once did a student in a whole-class discussion describe herself as Christian and provide commentary based on this personal perspective. Several students in the vocational programs who identified as Muslims expressed their position to the whole class. In that case, about one third of the students in the specific class articulated a Muslim position. At school 4, on the other hand, it was a given that the majority had a religious positioning. One of the students asked straight out in the class: "But isn't everyone here Muslim?" In the whole-class discussion, it was articulated that 22 of the students posed themselves as Muslims, one as Coptic Christian and one as Syrian Orthodox. It appears clear that the backgrounds of the students and the majority relation held in the classroom affected articulations and positions. Even in the classroom at school 4, the concept of secularization was raised and discussed:

Teacher: In some families, there are patriarchal structures. Then there are also is also a structure where you are much more gender-equal, depending on how liberal you are. Right? And how secular you are. Secular. Do you recognize these words again?

Student 1: Yes.

Student 2: Secular...

Teacher: What does this word mean then, secularized, or secular? Does anyone know what that means? If I am secularized, I am are very fundamentalist and I follow everything that is said and I live very much according to my book? Or are you more modern, do you think? Student 1: You are modern indeed.

Teacher: Yes. Right? And Sweden is usually a secular country. Right? You can interpret a bit as you wish. You can choose how much practicing you should be. Not everyone lives secularly in Sweden. But overall, Sweden is a very secular country compared with other countries. And the view on gender equality that exists in Sweden is that you should earn your own money, you should share the domestic work at home, it is very unique. Many other countries, religions, cultures, have a traditional division, with clear gender roles, clear rules for women and men (School 4).

Secularization was constructed as opposed to (religious) fundamentalism but foremost secularization was linked to modernity and this linking was very common in all classrooms. In this specific case, the discussion arose when the students were talking about different views of 
gender-equality related to religions. One interesting feature in this classroom (at School 4) compared with the other classrooms was that the majority articulated a religious position. It might be that there were students with non-religious worldviews who did not express this nonreligious position in the classroom. But it was simultaneously stressed that "Sweden" is a secular country and the discussions often included a minority perspective on various topics. Sweden was articulated as being a geographical area or a nation among others. The expression "we in Sweden" never occurred in this classroom.

\subsubsection{A "Chronocentric" Worldview}

Articulations that can be referred to as secularistic occurred in all classrooms but in various ways. This way of speaking was strongly influenced by a "chronocentric" view of history, which meant that we now live in the best and most enlightened of all ages. Religion was attributed to a historical remnant that possibly filled a function in the past. However, as modern enlightened people we now manage without religion, the reasoning went. The following quote is a typical example of this kind of reasoning:

Student: In the past, in the eighteenth century or so, or I think ... religion seeks power. One guesses about what has happened and that way they got power over people who didn't know very much. That's how it is in Islam ... so we think that it's so today as well. It's still like that. But now we're secularized and so we don't need religion in that way. Religion told us what to do, how we should live but there's no need for that anymore (School 1).

This student associated religion with the power and manipulation of people with less knowledge. It is interesting and quite typical that this student, who positioned himself as ethnically Swedish with "no religion", explicitly mentions Islam as an example of this kind of outdated view of life. In the past, people engaged in all sorts of strange things like different types of cruel bodily punishments, corporal punishment of children and medical treatments based on unscientific beliefs. Religion was often associated with these kinds of superstitions and delusions that modern enlightened people have seen through. Believers could, therefore, be perceived as "cheated", and students often mentioned ignorance or oppression as explanations for the existence of religion in different contexts.

\subsubsection{The Non-Religious as Neutral}

When speaking about religion, a non-religious, often explicit atheist position was articulated as a neutral and objective stance. Posing oneself as non-religious or atheist in classroom discussions was far more common both among teachers and students than positioning oneself as religious:

Student 1: Is there anybody here that is a believer?

Student 2: I think that ...

Student 3: I'm not like, I'm not a believer. I don't know. I haven't, like, had the energy yet to think about that

Student 4: I'm an atheist!

Student 1: My parents are, like, super-non-Christian, like, totally extreme. So, for me, it's like this: it's not very nice to say this but I feel this way-the Christians, it's unintelligent. I really think so! (School 1)

In this quote, religiosity was associated with unintelligence; the student who spoke here described herself an ethnically Swedish and positioned herself as an atheist. Taking an atheist position was not something that was questioned or queried. Unlike the ( $\mathrm{few}$ ) who posed as believers, students and teachers who described themselves as atheists were never asked questions about how they looked at life or what made them choose this way of life. At School 1, 2 and 3, students with a religious position expressed in private conversations that they many times felt questioned when religious issues were 
discussed and that they in these discussions were given opinions that they did not themselves embrace. It could be someone who asked how they could believe in "an old man on a cloud", that God created the earth in 6 days, or if they defended crusades, the IS or the Taliban. Questions about homosexuality and abortion were other areas where non-religious classmates expected believers to take a conservative position, which was not always the case. This type of onsets, sometimes concerning matters where students with a religious identity themselves were not sure about their opinion, contributed to that these students often held a low profile concerning their religious identity in the classrooms.

When talking about religion, speakers often made negations by denoting what religion was not associated with. For example: making individual choices, individualism and neutrality in binary opposites. Therefore, the speech of religion also contributed to defining a secular life view and worldview. Many students articulated a non-religious position as being neutral and objective; a religious position that was perceived to be biased.

Student 1: Secular? It's non-religious.

Student 2: Non-religious?

Student 1: Yes.

Student 2: But must it have to do with religion? Could it not be that it's optional, not optional but...

Student 3: I wrote objective too ...

Student 1: Like, secular, I think that's a strange word, but, like, multi-dimensional, that it should not be just one focus on something. And when it comes to religion, one should be allowed to have different religions in school.

Student 3: I have no idea what secular is. I thought it said secondary.

Teacher: They sometimes say that Sweden is secular.

Student 1: Well, yes, I understand vaguely what it means but I can't define the word.

Student 3: Non-religious, objective, I've written. That works, right?

Teacher: Yes, or, a little like this-that religion doesn't matter so much in society, so differentiating between religion and ...

Student 1: Yes, objective is a good word. (School 1)

The students were given a task of defining different concepts and it was clear that the students did not truly understand what the term "secular" meant. They associated the notion of words such as "freedom of choice", "objective", and "non-religious". When the teacher attempted to introduce explanations-including the role of religion in society-the students did not understand the meaning but concluded that secularization was equal to objectivity. Secularization, neutrality and objectivity were believed to be very similar in many classrooms.

Student 2: But, as for me, I don't follow any religion but I go by what I think!

Student 4: Yes.

Student 2: Religions are more like people who just blurt out a load of things that you yourself don't believe in.

Student 1: I'm neutral!

Student 4: Exactly! (School 3)

Again, we see how neutrality is associated with a non-religious position. We also see that religious positions are constructed in opposition to individualism and making one's own individual choices. Individualism appeared in classroom conversations as an overall value. 


\subsubsection{Individualism}

Making one's own individual choices and not being ruled or influenced by others was crucial to being perceived as a modern rational, independent individual. Individualism was also portrayed as being difficult when one was part of a collective, such as a religious group. Religion was strongly associated with blind obedience and submitting to irrational and often incomprehensible rules. Believing students were careful to emphasize that they also made conscious choices:

Student 2: Yeah but things that religions say that you should follow. Because you belong to this

Student 1: Just because it is so.

Student 2: Yes, because you belong to this religion. But I don't feel like that. Sure, I'm a Muslim but I don't do ... [what] people say, what THEY want me to believe in

Student 1: You decide!

Student 2: Yeah! Right! (School 3)

Many students perceived that religious individuals gave up their independence and individualism and simply followed a doctrine. In teaching, it was common to list what was referred to as "religious rules", which described how believers of specific religions were expected to eat, dress, celebrate their festivals, pray and follow the instructions of religious leaders. The fact that there are an infinite variety of approaches to these kinds of rules rarely came to the forefront in conversations among religious or non-religious individuals. To do anything at all with reference to religion or God (which was often described as "made up" or "an imaginary friend") was, in principle, impossible if one wanted to appear to be an independent, individualistic Swede.

\subsection{Discourses of Pluralism and/or Monoculturalism}

Another premise in the classroom was that society is multicultural. Pluralism was not something that was explicitly discussed or defined. The analysis of the transcribed classroom observations revealed that pluralism was articulated in terms of a diversity of opinions. However, this situation might also create uncertainty, which could lead to an identity crisis. Thus, pluralism was stressed as a fundamental Swedish value but at the same time, notions of pluralism were sometimes constructed as opposing or challenging notions of "Swedishness".

\subsubsection{Diversity of Views}

An educational strategy used by many teachers was to ask the students to compare religious views within various religious traditions and compare those with their own views. In the example below, the teacher asked the students to elaborate on the thesis of Martin Luther and to think about how Martin Luther would address them he was to nail them to the door in Wittenberg today:

Teacher: Those questions you got, are there some that you definitely can't find the answer to?

Student 1: "If Luther were active today, what would his theses be about, do you think?" That nobody believes in God anymore?

Teacher: What were the theses about? [Name of a student]?

Student 2: But what would his theses be about if he were alive today?

Teacher: Yes, that's right. But I can't help you with this. You have to figure it out yourselves. Student 2: But I don't believe in God. There's evidence that Jesus didn't create the Earth or anything. Just as an example. There's evidence of that, right?

Teacher: So you're saying that his theories were about concrete things that have already been solved today now so there's nothing?

Student 2: I don't know what they're all about! 
Student 3: Wasn't he like a theologian or something like that? Isn't it those who believe in the message and the ... well, religion? He based it on things like that but we don't believe that's the truth, you could say. And now we know much more about all the other religions and so. Now we know more.

Teacher: Would he have had as much success today if he'd gone on to re-formulate or to reinterpret the scriptures?

Student 3: No.

Student 1: No.

Teacher: Why not?

Student 1: Much easier to believe in different things now.

Teacher: Mm, there's an openness now that makes it very difficult to become an authority or be a leader today, right? And as you so rightly said, there are of course MANY different religions. And especially from here [in Sweden], we have an overview of many religions (School 2).

The students had difficulty answering, partly because they had vague presuppositions about the background to the Reformation but also because they rejected a religious worldview and stated that "There is evidence that Jesus did not create the Earth". The discussion also deals with the diversity of perceptions-one of the students states that it is "Much easier to believe in different things now". This statement can be seen as pluralism being an obvious part of existence- the teacher emphasizes Sweden as a place in which the religious diversity is significant, a situation that complicates trust in authorities.

Living in a society characterized by a diversity of perceptions, worldviews and lifestyles were articulated as a self-evident and non-questionable premise. In the following quote, questions about truth are also highlighted:

Student: So, in the olden days, one used to be more confident, that [religion] was the only thing available. Now nobody knows what is true, that is, you can't know that it's the truth, instead, one can only speculate as to what to believe, if you believe that it's true or not (School 1).

These classroom discussions illustrate one of the primary features of secularization according to Taylor [21], namely that a diversity of views in itself contributes to the secularization process.

\subsubsection{Encounter with "The Other"}

The student who spoke in the section above states that diversity leads to uncertainty-what should you believe in and what is true? Another student emphasized migration as a factor contributing to a religious identity crisis:

Student 1: We in Western Europe have lost more and more of our religion. And then some people come along [through migration] who might have a stronger faith than we do in many cases. Not everyone has to have that but quite a few do anyway. Not everybody is an extremist. However, what happens is that we in Western Europe, we feel this "where did our identity go, should we not keep our religion". You feel threatened by a threat that may not even actually exist (School 1).

It is in encounters with others who are perceived to have "stronger faiths" that questions about one's own identity appear. This student identifies with Western Europe and it was also common to refer to "we in Sweden", "we Swedish". Perceptions of the nation might have a bonding role. But references to the nation might also have a differential function. In the articulations of "we", "the other" is also constructed. The othering of the religious is constructed through articulations about people with 
"stronger faith", of which some are "extremists" are. Related to discourses of pluralism are discourses of mono-culturalism.

At School 4, where the hegemonic classroom discourse included articulations that all students positioned themselves as believers, no fear of other people's worldviews, religious or non-religious was articulated. On the contrary, these students articulated a diversity of views as something positive and something they perceived as being enriching. They also stressed the importance of the teacher's approach in creating a positive attitude about diversity:

Student 1: I think the teachers' work means quite a bit, it has been quite good, because they have learned now that even they, the new arrivals [need to be taught], that you should think openly. Now I do not know how they teach those newly arrived but I'm sure they [the teachers] are very careful with human rights and openness and so, to accept everyone's rights and so forth. And in that way now type ... we now know that your religion is yours. We cannot influence it, you believe what you want. Because we also have some Christians. I know two. Two who are Christian in our class. And they may say what they want but we can talk to them. You know, especially in RE.

Student 2: You are open.

Student 1: Yes, we say like "yes, we think like this", and then they say "no but it's like this". Still, there are only discussions but it's not like humiliating someone or going against someone. They may say "yes, I'm going to church ... I'm going to read the Bible today"

Interviewer: It turns out to be interesting conversations?

Student 1: Yes, then, so, we say, "What does the Bible say about this? What does the Quran say about this? "And then we are discussing. It's just ... yes. Then see, just that ... then there's also another person in our class from Thailand. Yes, that's Buddhism and so on. And then that's like, "What does your religion say about this?" So, it's more like curiosity (School 4).

During the observations at this school, it was noted that a clear majority of students stated that they regarded themselves as Muslim; there were also many who described themselves as Christian. On the other hand, I did not meet anyone who articulated an atheist position. At the same time, there was an awareness that an atheistic worldview was a common position in Sweden. The proportions and compositions of the student group concerning experiences and worldview influenced what was articulated in the classroom and therefore could the subject of discussion. Based on these observations, it is clear that a student group's own experiences and perceptions strongly influenced the ways in which a discussion took place. At the same time, how teachers raised different issues and stated decisively what is possible to learn in the classroom also colored the discussions.

\subsubsection{Pluralism and Processes of Change of Religious Traditions}

Pluralism is taken to be a hallmark of Swedish society but pluralism and secularization also affect religions, which change in this process.

Teacher: You think of Sweden as such a pluralistic country, that we believe in many different religions. We can choose whether we want to be atheists or how we want to live. We choose very much by ourselves, right? And Islam is also influenced by this. And Christianity too. But this is still one of the most important points. Then it is the case that many Muslims sort of do as they wish. There are also Muslims who are secular. Who are a bit more modern, who eat pork and so on, yet who are still Muslims. So you can't say that "you're not a Muslim because..." like that. "You're not wearing a veil so you're not Muslim". On the contrary, in Sweden there is still a choice (School 3).

During the observations, there was generally a tendency to talk about world religions in relatively static and generalizing terms and there was a strong focus on beliefs. The inner variation in the 
religious traditions was rarely visualized and exemplified in teaching if the students themselves did not specifically bring attention to this topic. In the class in the above quote, there were visual signs that made the teacher was aware of the diversity in the classroom-some of the Muslim girls wore hijabs, some did not. Diversity is not always visible in this way but nevertheless exists in most classrooms. In the case above, there were problems in the class with students accusing one another of not being a "real Muslim", and the teacher emphasized the inner variation of the religious traditions and connected it to individual freedom in Sweden. This situation highlights the complexity but also the importance of visualizing and exemplifying different positions and views within worldviews. To note the various interpretations is not enough. Rather, to make the students understand teachers need to show and give examples about how different individuals and groups relate to various matters.

\subsubsection{Pluralism and Tolerance in Principle but Secularity as the Norm}

In the relationship between secularization and pluralism, secularity is the norm. The following quote is a typical example of how two guys who describe themselves as "uninterested by religion" relate to their friends' religious identity:

Student 1: Our friends, many of our friends are Muslims. On our football team, there are many Muslims.

Teacher: Well, maybe you grew up with a certain knowledge that it might not be so incredibly strange, really.

Student 2: Our friends, the Muslims I know, they do it to make things easier. They do not care at all about their religion, really. They do it just because of their parents and hanging out with family during Ramadan and that kind of stuff, they just go with the flow.

$[\ldots]$

Student 1: They're out partying and whatnot, they don't care at all about that. I don't know if they've been influenced by us or something. Because the Muslims have Swedish buddies and Swedes have Muslim friends and there will be the lessons learned from each other as well (School 1)

Pluralism was perceived as evident and unproblematic. Nevertheless, it is worth noting that secularity is represented as a norm-it is acceptable to be Muslim as long as you behave "like everyone else" and religion does not affect you "too much". Another interesting aspect of the quote above is that the students use the epithets "Swedes" and "Muslims" as two categories; it is implied that Swedes are not Muslims. Therefore, the prerequisite for acceptance appears to be as to behave according to a secular norm and maintaining one's religion as a privatized part of one's life.

Being tolerant of different types of inequality was emphasized in many contexts as being very important. In many cases, tolerance was articulated as a central value in a multicultural society. At the same time, there were also limits to this tolerance. When it came to concrete expression, tolerance was significantly lower for religious expressions and practices that were perceived as "foreign". It was also clear that there was an intense striving for consensus in many classrooms and that it was difficult to deal with diverging opinions. It is interesting to note that tolerance was associated with a neutral, non-existent position while religiosity was associated with intolerance.

\section{Discussion}

The purpose of this article was to illustrate and analyze how issues of secularization and pluralism appeared in the classroom practice and how these two social phenomena were related in the classroom. Both secularity and pluralism emerged in many ways as premises to conversations about religion. During the classroom observations, articulations of attitudes about believers as being irrational and an outdated remnant of history was noted. Anyone is entitled to have this entirely legitimate opinion. However, if this approach dominates in the classroom it will be difficult to achieve goals that involve 
understanding what it may mean to have faith. Furthermore, the students will not be prepared to live in a society characterized by diversity, which is one of the purposes of RE [7]. The results reflect a common way to relate to religion in Swedish society, a place where many people have an ambivalent relationship towards religion. On the one hand, it seems extremely important for many students and teachers to distance themselves from religion in order to appear to be rational and independent individuals. In these contexts, religion has been made into something those others who do not know better or are oppressed in different ways engage in. In this context, Sweden is referred to as "the world's most secularized country", and this self-image has a positive connotation and includes perceptions of anti-racism, tolerance and a positive attitude toward diversity. Here, one can ask the question how tolerant "we" are in Sweden; how much "difference" do "we" really like? Students in the classrooms often said that everybody was allowed to believe in whatever they wished. However, when it came down to concrete opinions and practices, tolerance was not as unlimited and many students expressed that "they" (which usually referred to Muslims) should adapt to "us" who were secularized or possibly privately religious when it came to issues such as clothes, food and behavior. As in other parts of society, there was a strong pursuit of consensus after constructing a solid "we". In classroom discussions about religion the use of the pronoun "we" always had to national mono-cultural connotations, "we in Sweden". In many cases, Sweden as a secular country and nonreligious identity was stressed but in relation to Islam, the Christian history and heritage was emphasized. In School 4 where $91 \%$ of the student had a 'foreign background,' the expression "we in Sweden" never occurred. One of the challenges of the school system and society is to create a sense of belonging because all of these teens are part of the same society.

On the one hand, both teachers and students articulated positive words about diversity and pluralism. On the other hand, it appeared difficult to deal with different views in the classroom practice and a secular discourse dominated the classroom conversations in many cases. One can also think about what makes a discourse hegemonic in a certain context. When a discourse becomes hegemonic, speaking in a certain way about a phenomenon emerges as self-evident. This way of speaking is perceived as neutral and objective [66]. If a discourse becomes hegemonic, it affects both what and how something is articulated and also what is not possible to articulate. If a secularist discourse is hegemonic, religion becomes a private matter, which makes it difficult to express religious positions or opinions related to this position. In this article, the classroom is understood to be a discursive practice. Whether it is possible or impossible to articulate sometime is influenced and framed by a variety of factors (e.g., the school subject, the content of the curriculum and the syllabus, the teacher's knowledge and understanding of the subject and choice of teaching strategies). However, articulations in the classrooms are also influenced by how the surrounding community addresses the same issues and the students' personal experiences with these issues [5]. The students' personal knowledge, experiences and perceptions, have a major impact on conversations. Sometimes the students' perceptions are characterized by a lack of religious literacy and this will affect the classroom conversations. As outlined above it was at all schools more common for students to state a Muslim identity in the classroom than for students to state a Christian identity and this is also noted in other studies [31]. The reasons for this might be related to Islam, ethnicity, a minority position or social class or the interplay between these factors. Eriksen ([50], p. 272) notice the same phenomena and asks "Is 'being Christian' about belief, whereas 'being Muslim' just something you are"? Due to these various approaches to religion, the identity might be affected in various ways by the secularist discourse of religion. Furthermore, the majority relationships in the specific classroom as well as the group- and identity-processes at play seems to be of crucial importance. Over the past few years, I have carried out hundreds of classroom observations. During these classroom observations, I have been struck by how few students participated in full-class discussions. There are rarely more than 4-6 students who are active and interacting with the teacher. The vast majority of students are mostly silent or do not actively participate in the collective conversation. This situation implies that just a few students' views have a significant influence on the entire conversation. Being silent cannot 
be equated with not actively involved and being silent also influences the classroom discussion. However, the teachers act on and move the teaching according to what he/she comprehends to be the understanding of the students. If a large group is silent, it is hard to recognize what they think or how they understand the subject matter and thus the possibilities to adjust the teaching in order to reach these students and enhance their learning.

There are many competing views and beliefs, a situation that Taylor [21] emphasizes as one of the main characteristics of secularization. This fact is evident in the analysis of the classroom discussions. Hervieu-Léger [26] argued that secularization has meant a changed approach to religious traditions. Narratives and practices that worked for previous generations as a starting point for a common understanding of both their own identity and their understanding of the outside world are now fragmented. Several of the quotes in this article can be seen as an example of this fragmentation and several of the students expressed a sense of bewilderment and loss of what they could relate to concerning existential issues and worldviews. At the same time, other individuals and groups are socialized into specific religious traditions and are confident in their identity. So, while pluralism is viewed as one of the primary characteristics of secularization, much of the public discourse about the multicultural society concerns pluralism in the form of people with religious beliefs challenging secular society. This takes place in the wake of "the war on terrorism" and an increasingly polarized context where populistic and right-wing activists try to gain influence through constricting Islam as a threat and claiming that there is an ongoing Islamization of the West. When students with different experiences and relations to religion and opinions about pluralism and secularity meet, uncertainties sometimes arise partly because there is no shared understanding of the religious dimension of life. Pupils who position themselves as non-believers do not always have a language to formulate in life-viewing issues. Research on how secularization affects identity and life interpreting has identified the need for new linguistic tools in secular and multicultural environments [53]. Human beings are meaning-creating by nature and will always try to understand and make sense, even if doing so requires new expressions in new contexts. Secularization and pluralism can, on the one hand, be seen as fragmentation but this form of change can also be understood as a transformation or a hybridization in which religions and worldviews take on new expressions and characters and possibly new 'religions' emerging. However, it can be difficult to identify new natures of meaning-making take during the process of change.

Internationally, there are several different models of RE in public school systems. In some countries, RE is not offered as a subject; in some countries, students are divided on the basis of religious belonging. In other countries, it is only possible to have RE in the majority religion. Given the choice between these options, the model in which students with different backgrounds meet in classrooms and gain knowledge about different traditions, differences and similarities in approach within and between different religious traditions is a good alternative. In this context, groups have the opportunity to discuss various aspects of worldviews. Although Swedish society and schools are segregated in many ways, the segregation is not total and there are still opportunities for students from different socio-economic, cultural and religious backgrounds to meet at school. Classrooms in a pluralistic society can be described in terms of un-generalizable classrooms. If students are not divided along religious affiliation lines there is a greater chance that they will meet students with a different worldview than themselves and thus learn more. Nevertheless, the premise is that the classroom is characterized by curiosity and respect and that was, as shown in the empirical examples in this article, not always the case. These kinds of places, where people from a diverse tapestry of beliefs and backgrounds meet, are becoming rarer in a time strongly influenced by forums that we choose based on common interests and backgrounds. In Facebook feeds, for example, pages that people have previously liked pop up again; we become Facebook friends with our friends' friends. This situation means that we rarely find ourselves in a context in which people have different views than ourselves. School plays an essential role in training children and young people to discuss various issues to reveal how complex, contradictory and multifaceted they truly are. The reality is complicated 
and it is possible to approach different problems from a variety of perspectives. To practice and to learn to relate to social issues from different perspectives is a crucial competence in a democratic society and RE can contribute to achieving this competence.

Teaching must navigate social controversies and students who maintain different political, ethnic and religious positions. On the one hand, schools should convey specific democratic values such as equality, tolerance and respect for all human beings. On the other hand, teaching needs to facilitate conversations and discussions where the answers are not given in advance. At the same time, society is becoming more individualistic and pluralistic and the classrooms increasingly un-generalizable which ever more makes it a challenge to find the commonality in diversity while still maintaining individuals' identities. All education must relate to questions about how individuals and groups with different interests and belongings can communicate with one another and be part of the same society [68]. By problematizing different social positions and positions in the classroom, students learn how to handle equality, inequality, conflicts and controversial issues, which creates the conditions that facilitate a better understanding of themselves and society. In terms of the Swedish curriculum, which states that that each student should be given the opportunity to develop his or her own character while preparing to be able to share and contribute to society "in responsible freedom" [6], there are prerequisites for constructing an education that recognizes and respects a unique "me" and simultaneously makes opportunities for creating a multifaceted "we".

Funding: The research in this article was partly funded by the Swedish Research Council.

Acknowledgments: I am very grateful to all the teachers and students who shared their classroom practices and experiences.

Conflicts of Interest: The author declares no conflict of interest. The founding sponsors had no role in the design of the study; in the collection, analyses, or interpretation of data; in the writing of the manuscript and in the decision to publish the results.

\section{References}

1. Zuckerman, P. Why are Danes and Swedes so Irreligious? Nord. J. Relig. Soc. 2009, 22, 55-69.

2. Thurfjell, D. Det Gudlösa Folket: De postkristna Svenskarna och Religionen [The Godless People: The Post-Christian Swedes and Religion]; Molin and Sorgenfrei: Stockholm, Sweden, 2015.

3. Tomasson, R.F. How Sweden became so secular. Scand. Stud. 2002, 74, 61-88.

4. Andersson, D.; Sander, Å. Det Mångreligiösa Sverige: Ett Landskap i Förändring [The Multi-Religious Sweden: A Changing Landscape]; Studentlitteratur: Lund, Sweden, 2015.

5. Nilsson, S. Det oförutsägbara klassrummet-utmaningar och möjligheter [The Unpredictable Classroom-Challenges and Opportunities]. In Interkulturell Religionsdidaktik-utmaningar och Möjligheter [Intercultural Pedagogic of Religious Education-Challenges and Oppurtunities]; Franck, O., Thalén, P., Eds.; Studentlitteratur: Lund, Sweden, 2018; pp. 109-129.

6. Skolverket. Läroplan, Examensmål och Gymnasiegemensamma ämnen för Gymnasieskola 2011, Lgy 11 [Curriculum for the Upper Secondary School]; Utbildningsdepartementet, The Swedish National Agency for Education: Stockholm, Sweden, 2011.

7. Skolverket. Ämnesplan Religionskunskap [Syllabus of Religion]; Utbildningsdepartementet, The Swedish National Agency for Education: Stockholm, Sweden, 2011.

8. Kittelmann Flensner, K. Discourses of Religion and Secularism in Religious Education Classrooms; Springer: Cham, Switzerland, 2017.

9. Holmqvist Lidh, C. Representera och bli Representerad. Elever med RELIGIÖS Positionering Talar om Skolans Religionskunskapsundervisning [Represent and Be Represented. Pupils with Religious Positioning Talk about Teaching in Religious Education; Karlstads universitet: Karlstad, Sweden, 2016.

10. Moulin, D. Giving Voice to 'the Silent Minority': The Experience of Religious Students in Secondary School Religious Education Lessons. Br. J. Relig. Educ. 2011, 33, 313-326. [CrossRef] 
11. Jannert, H.; Persson, C. Interkultulturell religionsundervisning i praktiken [Intercultural Religious Education Teaching in Practice]. In Interkulturell Religionsdidaktik-Utmaningar och Möjligheter [Intercultural Pedagogic of Religious Education-Challenges and Oppurtunities]; Franck, O., Thalén, P., Eds.; Studentlitteratur: Lund, Sweden, 2018; pp. 131-177.

12. Franken, L. Coping with Diversity in Religious Education: An Overview. J. Beliefs Values 2017, 38, $105-120$. [CrossRef]

13. Skolöverstyrelsen. Läroplan för Grundskolan (Lgr 62) [Curricula for the Compulsory School]; Skolöverstyrelsens Skriftserie: Stockholm, Sweden, 1962.

14. Flensner, K.K.; Larsson, G. Swedish Religious Education at the End of the 1960s: Classroom Observations, Early Video Ethnography and the National Curriculum of 1962. Br. J. Relig. Educ. 2013, 36, $202-217$. [CrossRef]

15. Grimmitt, M. Religious Education and Human Development; McCrimmons: Great Wakering, UK, 1987.

16. Willaime, J.-P. Different models for Religion and Education in Europe. In Religion and Education in Europe: Developments, Contexts and Debates; Jackson, R., Miedema, S., Weiße, W., Willaime, J.-P., Eds.; Münster: Waxmann, Germany, 2007.

17. Af Burén, A. Living Simultaneity: On Religion among Semi-Secular Swedes; Södertörns Högskola: Huddinge, Sweden, 2015.

18. Dobbelaire, K. The Meaning and Scope of Secularization. In The Oxford Handbook of the Sociology of Religion; Clarke, P.B., Ed.; Oxford University Press: Oxford, UK, 2009.

19. Cassanova, J. Beyond European and American Exceptionalism: Towards a Global Perspective, in Predicting Religion: Christian, Secular and Alternative Futures; Davie, G., Heelas, P., Woodhead, L., Eds.; Ashgate: Aldershot, UK, 2003.

20. Johnstone, R.L. Religion in Society: A Sociology of Religion; Pearson/Prentice Hall: Upper Saddle River, NJ, USA, 2007.

21. Taylor, C. A Secular Age; Belknap Press of Harvard University Press: Cambridge, MA, USA, 2007.

22. Beckford, J.A. Re-Thinking Religious Pluralism, in Religious Pluralism: Framing Religious Diversity in the Contemporary World; Giordan, G., Pace, E., Eds.; Springer: Cham, Switzerland, 2014.

23. Skeie, G. The Concept of Plurality and its Meaning for Religious Education. Br. J. Relig. Educ. 2002, 25, 47-59. [CrossRef]

24. Thalén, P. Att vara religionslärare i en tid av radikal mångfald [To be a Teacher of Religious Education in Times of Radical Plurality]. In Interkulturell Religionsdidaktik-Utmaningar och Möjligheter [Intercultural Pedagogic of Religious Education-Challenges and Oppurtunities]; Franck, O., Thalén, P., Eds.; Studentlitteratur: Lund, Sweden, 2018; pp. 179-194.

25. Berger, P.L. The Sacred Canopy: Elements of a Sociological Theory of Religion; Doubleday: Garden City, NY, USA, 1969.

26. Hervieu-Léger, D. Religion as a Chain of Memory; Polity Press: Cambridge, UK, 2000.

27. Madge, N.; Hemming, P.J.; Stensonet, K. Youth on Religion: The Development, Negotiation and Impact of Faith and Non-Faith Identity; Routledge: New York, NY, USA, 2013.

28. Valk, P.; Bertram-Troost, G.; Friederici, M.; Béraud, C. (Eds.) Teenagers' Perspectives on the Role of Relgion in Their Lives, Schools and Societies. A European Quantitative Study; Waxmann: Münster, Germany, 2009.

29. Ziebertz, H.-G.; Kay, W.K.; Riegel, U. Youth in Europe III: An International Empirical Study about the Impact of Religion for Life Orientation; Lit Verlag: Berlin, Germany, 2009.

30. Day, A. Believing in Belonging: Belief and Social Identity in the Modern World; Oxford University Press: Oxford, UK, 2011.

31. Knauth, T. "Better Toghther Than Apart" Religion in School and Lifeworld of Students in Hamurg. In Religious Diversity and Education in Europe; Bakker, C., Berglund, J., Bertram-Troost, G., Ipgrave, J., Heimbrock, H.-G., Jackson, R., Skeie, G., Weisse, W., Eds.; Waxmann: Münster, Germany, 2008; pp. 207-245.

32. Knauth, T.; Jozsa, D.-P.; Bertram-Troost, G.; Ipgrave, J. Encountering Religious Pluralism in School and Society. A Qualitative Study of Teenage Perspectives in Europe; Waxmann: Münster, Germany, 2008.

33. Davie, G. The Sociology of Religion. BSA New Horizons in Sociology; SAGE: London, UK, 2007.

34. Ter Avest, I.; Jozsa, D.-P.; Knauth, T.; Rosón, J.; Skeie, G. Dialogue and Conflict on Religion. Studies of Classroom Interaction in European Countries; Waxmann: Münster, Germany, 2009. 
35. Bromander, J.; Lövheim, M. Religion som Resurs? Exitentiella FRÅGOR och värderingar i unga Svenskars liv [Religion as a Resource? Exitential Questions and Values in the Lives of Young Swedes]; Artos \& Norma bokförlag: Skellefteå, Sweden, 2012.

36. Risenfors, S. Gymnasieungdomars Livstolkande [Upper Seccondary Youth's Life Interpretations]; Acta Universitatis Gothoburgensis: Göteborg, Sweden, 2011.

37. Sjöborg, A. Religious Education and Intercultural Understanding: Examining the Role of Religiosity for Upper Secondary Students' Attitudes Towards RE. Br. J. Relig. Educ. 2013, 35, 36-54. [CrossRef]

38. Von Brömssen, K. Time and 'the Other/s,' Scientism and Gender-Statements: Discourses on Religion in a Swedish 'Multi-Cultural' School. In Your Heritage and Mine. Teaching in a Multi-Religious Classroom; Roos, L., Jenny, B., Eds.; Religionshistoriska Avdelningen, Uppsala Universitet: Uppsala, Sweden, 2009; pp. 94-106.

39. Von Brömssen, K. Some ethnic Swedish Students' Discourses on Religion: Secularism Par Excellence. J. Relig. Educ. 2016, 2, 113-125. [CrossRef]

40. Davis, D.; Miroshnikova, E.M. The Routledge International Handbook of Religious Education; Routledge: Abingdon, Oxon, UK, 2013.

41. Rothgangel, M.; Skeie, G.; Jäggle, M. Religious Education at Schools in Europe. Part 3, Northern Europe; Vienna University Press: Göttingen, Germany, 2014.

42. Anker, T. Respect and Disrespect: Social Practices in a Norwegian Multicultural School; MF Norwegian School of Theology: Oslo, Norway, 2011.

43. Buchardt, M. When 'Muslim-ness' is pedagogised. 'Religion' and 'Culture' as Knowledge and Social Classification in the Classroom. Br. J. Relig. Educ. 2010, 32, 259-273. [CrossRef]

44. Merchant, N.H. Between a Rock and a Hard Place: Shia Ismaili Muslim Girls Negotiate Islam in the Classroom. Diasp. Indigen. Minor. Educ. 2016, 10, 98-111. [CrossRef]

45. Merchant, N.H. Responses to Islam in the Classroom: A Case of Muslim Girls from Minority Communities of Interpretation. Int. J. Multicult. Educ. 2016, 18, 183-199. [CrossRef]

46. Osbeck, C.; Lied, S. Hegemonic Speech Genres of Classrooms and Their Importance for RE Learning. Br. J. Relig. Educ. 2011, 34, 155-168. [CrossRef]

47. Von der Lippe, M. Young People's Talk About Religion and Diversity: A Qualitative Study of Norwegian Students Aged 13-15. Br. J. Relig. Educ. 2011, 33, 127-142. [CrossRef]

48. Brubaker, R. Religion and Nationalism: Four Approaches. Nations Natl. 2012, 18, 2-20. [CrossRef]

49. Bayat, A.; Herrera, L. Being Young and Muslim: New Cultural Politics in the Global South and North; Oxford University Press: New York, NY, USA, 2010.

50. Eriksen, L.L. Learning to Be Norwegian. A Case Study of Identity Management in Religious Education in Norway. Ph.D. Thesis, University of Warwick, Warwick, October 2010.

51. Ostberg, S. Norwegian-Pakistani Adolescents: Negotiating Religion, Gender, Ethnicity and Social Boundaries. Young 2003, 2, 161-181. [CrossRef]

52. Ryan, L. 'Islam does not Change': Young People Narrating Negotiations of Religion and Identity. J. Youth Stud. 2014, 17, 446-460. [CrossRef]

53. Gustavsson, C. Existentiella Konfigurationer: Om hur Förståelsen av Livet tar Gestalt i ett Socialt Sammanhang [Existential Configurations: How the Understanding of Life Takes Shape in a Social Context]; Stockholms Universitet: Stockholm, Sweden, 2013.

54. Gustavsson, C. Språkliga redskap för en gränsöverskridande interkulturell religionsundervisning [Linguistic Tools for Cross-border Inter-cultural Religious Education]. In Interkulturell Religionsdidaktik-Utmaningar och Möjligheter [Intercultural Pedagogic of Religious Education-Challenges and Oppurtunities]; Franck, O., Thalén, P., Eds.; Studentlitteratur: Lund, Sweden, 2018; pp. 235-252.

55. Sieben, I.; Zundert, M.V.; Halman, L. Atlas of European Values. Trends and Traditions at the Turn of the Century; Brill: Leiden, The Netherlands, 2012.

56. Bromander, J. Religiositet i Sverige [Religiosity in Sweden]. In Vägskäl; Weibul, L., Oscarsson, H., Bergström, A., Eds.; SOM-Institutet: Göteborgs, Sweden, 2013; pp. 291-301.

57. Stockman, M.; Carnbo, I. Trossamfund i Sverige: Statsbidragsberättigade Trossamfund 2017: Presentationer och Aktuell Statistik [Religious Communities in Sweden: State Grants to Religious Communities 2017: Presentations and Current Statistics]; Nämnden för Statligt stöd till Trossamfund: Bromma, Sweden, 2017.

58. Von Bromssen, K.; Olgac, C.R. Intercultural Education in Sweden through the Lenses of the National Minorities and of Religious Education. Int. Educ. 2010, 21, 121-135. [CrossRef] 
59. Swedens Population 2017-Population Changes: New Swedish Citizens from 160 Countries. Available online: http://www.scb.se/en/finding-statistics/statistics-by-subject-area/population/populationcomposition/population-statistics/pong/statistical-news/swedens-population-2017--populationchanges2/ (accessed on 21 March 2018).

60. Statistics Sweden. Population Statistics. Available online: http://www.scb.se/en/finding-statistics/ statistics-by-subject-area/population/population-composition/population-statistics (accessed on 25 May 2018).

61. Utbildningsdepartementet. Samling för Skolan. Nationell Strategi för Kunskap och Likvärdighet: Slutbetänkande från 2015-års Skolkommision [Together for School: National Strategy for Knowledge and Equivalence: Final Report]; Wolters Kluwer: Stockholm, Sweden, 2017.

62. Heaton, J. Secondary Analysis of Qualitative Data: An Overview. Hist. Soc. Res. 2008, 33, 33-45.

63. Gordon, T.; Holland, J.; Lahelma, E. Ethnographic Research in Educational Settings. In Handbook of Etnography; Atkinson, P., Coffey, A., Delamont, S., Lofland, J., Lofland, L.H., Eds.; SAGE: London, UK, 2007; pp. 188-203.

64. Corsaro, W.A. The Sociology of Childhood. Sociology for a New Century; Pine Forge Press: Thousand Oaks, CA, USA, 2005.

65. Howarth, D. Discourse; Open University Press: Buckingham, UK, 2000.

66. Laclau, E.; Mouffe, C. Hegemony and Socialist Strategy: Towards a Radical Democratic Politics; Verso: London, UK, 2001.

67. Hermerén, G. Good Research Practice; The Swedish Research Council: Stockholm, Sweden, 2011.

68. Touraine, A. Can We Live Together: Equality and Difference; Polity: Oxford, UK, 2000.

(C) 2018 by the author. Licensee MDPI, Basel, Switzerland. This article is an open access article distributed under the terms and conditions of the Creative Commons Attribution (CC BY) license (http:/ / creativecommons.org/licenses/by/4.0/). 